\title{
The North and South Divide in the Practice and Application of International Law: A Humanitarian and Human Right Law Perspective
}

\author{
Abdul Hamid Kwarteng ${ }^{1} \&$ Thomas P. Botchway ${ }^{2}$ \\ ${ }^{1}$ School of Law, Zhongnan University of Economics and Law, Nanhu Avenue, China \\ ${ }^{2}$ Law School, Chongqing University, Shapingba, Chongqing, China \\ Correspondence: Abdul Hamid Kwarteng, Zhongnan University of Economics and Law, 182\# Nanhu Avenue, \\ East Lake High-tech Development Zone, Wuhan 430073, China. Tel: 86-156-2327-9576. \\ E-mail:kwarteng115@yahoo.com
}

Received: December 24, 2017 Accepted: January 9, 2018 Online Published: February 25, 2018

doi:10.5539/jpl.v11n1p79

URL: https://doi.org/10.5539/jpl.v11n1p79

\begin{abstract}
The North and South divide in the practice and application of international laws have been previously perceived to be evident in international environmental law where the Global developed North countries on the one hand advocate for a collective action to protect the environment while the Global developing Southern countries, on the other hand, argue for social and economic justice in practice. However, in recent times the North and South divide has permeated other aspects of international law such as International Human right and International Humanitarian law (IHL), hence the essence of this article. Thus, this article contributes to the existing literature by providing evidence to the existence of the North and South divide in the application of IHL and human right law.

The article is divided into four main parts. The first part gives an introduction to the North and South divide in the application of international law. The second part reviews the literature on the existence of North and South divide in the application of international environmental laws. The third part gives a new dimension to the North and South divide in the application of international humanitarian and human right laws with the Syrian Crisis, Malaysian Airline flight MH17 and the 2007 draft resolution on the peace and security of Myanmar as the case studies. The last part concludes by giving an overview of how this phenomenon threatens world peace and consequently offers some recommendations.
\end{abstract}

Keywords: North and South divide, UN Security Council, the power of veto, International Humanitarian Law (IHL), international human right law, resolution

\section{Introduction}

The North and South divide in a general sense are viewed as a socio-economic and political divide. In a broader sense, the Global North (First World) generally refers to the richer and more developed countries like the United States, France, United Kingdom, Canada, New Zealand, and Australia among others. The term Global South, on the other hand, refers to developing countries like African Countries, Latin America, Russia and The People's Republic of China (Odeh, 2010).

According to Singh (2014), even though in recent times one can argue that China is experiencing rapid development in various sectors of the economy, it is still considered as part of the Global South developing countries. The reason for this is that China has a huge population and its per capita income is relatively low coupled with huge regional disparities in terms of development. Also with regards to human development index, China is ranked in the middle and if one takes a comprehensive analysis of China's negotiations with developed countries on matters of trade, environment, technology and climate change, it argues and negotiates from a developing country's perspective.

To a large extent, Russia is also a developing country because its Gross Domestic Product (GDP) per capita is $\$ 24,451$ with an infant mortality rate of eight per 1,000 and a Human Development Index (HDI) of 0.79 which is not quite encouraging (Investopedia, 2016). A developed country should have at least a GDP of $\$ 25,000$ even though a country like the United States of America has a GDP of $\$ 40,000$ or above (Investopedia, 2016). There is little or virtually no diversity in the Russian economy and the country depends highly on natural resources. 
Surprisingly, a country that once reigned side by side with the United States of America as a world superpower has little to show in terms of technological innovations in the $21^{\text {st }}$ century. Clearly speaking, Russia as at 2016 could still be regarded as a developing country.

The North/South divide in the practice and application of international law is a phenomenon that could be traced as far back as in the era of colonialism and has profoundly shaped the evolution of international law in present-day especially in the area of international environmental laws and climate change.

Existing literature that tries to provide evidence with regards to the North-South Divide in the practice and application of international law concentrate their arguments on the different position adopted by the Global South and Global North countries on international environmental laws and climate change. This article contributes to knowledge and the existing literature by providing a different dimension to that argument. Thus the article provides evidence to prove the existence of the North and South divide in the practice and application of international law from a human right and humanitarian law perspective and concludes by giving an overview of how this phenomenon has led to the destruction of millions of properties and the loss of millions of lives as well as the possibility of it threatening world peace and human right in general.

\section{Method of the Study}

The method adopted for this study is the case study approach employing qualitative analysis of data. This enabled the researchers to draw on practical evidence from the Syrian crisis of 2011 and the case regarding the shooting down of the Malaysian Airline flight MH17 in 2014, as well as the 2007 draft resolution on the peace and security of Myanmar so as to prove the existence of the North and South Divide in the application and practice of IHL and international human right laws. According to Creswell (2009), the case study approach enables the researcher to do a comprehensive and in-depth analysis of data, events, and processes.

The study relied on qualitative data for analyzing the subject under consideration. It consequently applies both primary and secondary sources of information which existed in the form of information from journal articles, the internet, policy documents, the dailies, press releases, news items, and official reports from relevant international institutions.

\section{Evidence of North/South Divide in the Practice and Application of International Environmental Laws}

International environmental law is one of the areas where one can examine the ways by which the conflict between the global North and global South has compromised the effectiveness of effort to protect the global environment. For example, Global developed Northern countries have often advocated for collective actions to protect the environment and emphasize that the North and the South are all in the same boat. Global developing Southern countries, on the other hand, have viewed these demands as hypocritical given the enormous ecological footprints that developed countries had on the environment during their process of development and have insisted that the Northern Governments should take the lead in addressing global environmental degradation because historically it is the actions of the now global developed North countries that degraded the environment (Wapner, 2003).

In the words of Anand (2017), the conflict between the countries of the Global North and that of the Global South has been the main hindrance preventing international environmental laws from achieving their purpose and objectives. He argues that environmental treaties and negotiations have failed to yield the intended results mainly because the Global North countries and the Global South Countries have different priorities and each of the parties will like to advance their priorities at the expense of the other hence it becomes difficult to reach a consensus.

Birnie \& Boyle (1994) in their work "International law and the environment" also state that the inability of international environmental laws to protect the environment as expected is as a result of the different opinions, perception, and positions adopted by countries of the Global North and that of the Global South. In their opinion, the North and South have a different perspective as to what the protection of the environment means and what policies should be put in place to ensure the protection of the environment. International environmental laws and agreements will achieve their intended purpose only when the Global South and Global North countries adopt a common stand on environmental protection.

Carlson (2012) states that the failure of international environmental laws to stop or reverse the continuous deterioration of the environment is because of the eminent divide between the countries of the Global South and that of the Global North. Thus in the view of the Global South developing countries, international environmental laws and policies proposed by the Global North developed countries is an attempt to subdue the developmental agenda of the former. Eventually, whereas the Global South Countries expected Global North Countries to take 
the lead in the protection of the environment, Global North countries, on the other hand, see the protection of the environment as a shared responsibility.

According to Bauer (2002), most developing countries like African countries rely mostly on natural resources for the development of their country. Governments of such countries are therefore tempted to tap and overuse such resources in order to generate income to solve the various pressing needs of their people and as such preserving the environment is not really a priority on the agenda and policies of most developing countries. Thus whiles developed countries in the Global North will advocate for policies that are aimed at environmental preservation and the minimal use of natural resources, developing countries in the Global South, on the other hand, see the intense use of such resources as the only means by which they can develop and as such any law or policy that is aimed at limiting the use of such resources is seen as anti-developmental and rejected.

Gonzalez (2015), in his article "Bridging the North-South Divide: International Environmental Law in the Anthropocene" argues that the globally developed North countries have historically emphasized that environmental problems are of a global concern that needs a holistic approach to address the issue. The Global South countries, on the other hand, prioritize the lessening and probably eradication of poverty over environmental issues. In the view of the Global South countries, the developed Global North countries are the major contributors to environmental problems of the world and as such they should assume the responsibility of finding solutions to the problems of the environment while the Global North countries, on the other hand, accept the principle of shared but differentiated responsibilities as a way of protecting the environment. This different viewpoint makes it difficult and probably impossible for international environmental laws to work effectively as expected.

For instance, at the Stockholm Conference in 1972, the then acting Indian Prime Minister Indira Gandhi is noted to have said that:

“... We do not want to impoverish environment any further, (but) we cannot forget the grim poverty of large numbers of people. When they themselves feel deprived how can we urge the preservation of animals? How can we speak to those who live ... in slums about keeping our oceans, rivers and the air clean when their own lives are contaminated at the source? The environment cannot be improved in conditions of poverty..." (Beyerlin, 2006 p. 264).

Natarajan \& Khoday, (2014) also assert that in most conferences held to enact policies and laws to protect the environment, there has always been a disagreement between the countries of the global North and those of the global South and the obvious reason is that the countries of the global North advocate for collective action to protect the environment whiles countries of the global South on the other hand demand for social and economic justice. Thus Global South Countries are of the view that during the developmental stages of the Global North Countries they did lots of harm to the environment through the use of factories, machines etc. and this has resulted in significant development of their economy and so it will be hypocritical for global North developed countries to prevent the global developing South countries to also use a similar way to advance their economy.

Therefore in the view of the developing countries, the global North countries should be responsible for fixing the problems they caused and that environmental protection laws and policies are tools and ways that the global North Countries want to use to hinder the developmental process of countries in the global South. On the other hand, global North countries disagree but rather see environmental protection as a shared responsibility between both developed and developing countries.

In the words of Beyerlin (2006), the ineffectiveness of international environmental laws is as a result of the fact that both the countries in the global North and global South tend to advance their own interest and needs which in most cases are opposed by each other. He argues that countries in the global North and that of the global South should be committed to protecting the environment by ensuring that measures aimed at protecting and preserving the environment are given priority in the developmental agenda and policies of both developed and developing countries. However current practices on international environmental issues clearly show that the interrelationship between the North and South is still characterized by distrust rather than respect for each other and a sense of common feeling aimed at protecting and preserving the environment.

The North and the South often have different and conflicting priorities. While some Northern environmentalist seek to protect wild lands and endangered species for their own sake, Southern countries have often emphasized environmental issues with immediate impacts on vulnerable population including desertification, food security access to safe drinking water, sanitation and access to clean energy.

The point must also be reiterated that the conflict between the Global North and the Global South is often 
articulated in two main languages namely Climate Debt and Climate Justice. Climate debt is a term coined in the global South to describe the imbalance between those who suffer and die from climate change and those who should bear primary responsibility for the problem. Climate debt theory, therefore, posits that the cost of climate change adaptation and compensation for injury and loss should be the responsibility of those who contributed most to the climate crisis. The second concept that has been used to frame the North/South Divide over climate change is referred to as Climate justice. Climate Justice Scholars have emphasized four distinct but interrelated dimensions of environmental justice. These scholars allege distributive injustice in the form of inadequate access by vulnerable communities to get access to parks and open space and exposure to environmental hazards such as toxic waste. They allege procedural unfairness due to the exclusion of socially and economically marginalized communities from environmental decision making. They also allege corrective injustice in the form of inadequate enforcement of the environmental laws and access to remedy for environmental harm. Finally, they emphasize social injustice because environmental degradation is inextricably intertwined with other social ills such as poverty and racism (Gonzalez, 2015).

Climate change raises the issue of "Distributive Justice" because the global developed North countries are the primary beneficiaries of the consumption driven and developmental model that is having a disproportionate impact on vulnerable states and vulnerable people. Climate change also raises the issue of "Procedural justice" because the North dominates the institutions of global economic and environmental governance including the International Monetary Fund (IMF), the World Bank, the World Trade Organization (WTO) and other multilateral environmental forum. Southern perspectives are frequently marginalized in these areas as a result of the dominance of the North in all the major international structures.

\section{The North and South Divide in the Application of IHL and International Human Right Law}

\subsection{A Brief Introduction of IHL and International Human Right Law}

International humanitarian law (IHL) and International human rights law are clearly different but complementary sets of law that are both concerned with the protection of life, property, health, and self-respect of persons. The distinction that can be drawn between the two is that IHL is mostly applicable in situations of conflict and war whiles the international human right law, on the other hand, is applicable in everyday life, both in times of war and peace. However, both IHL and international human rights law are applicable in armed conflict (ICRC, 2010). The distinction in the application of IHL and international human right laws is that International human right laws mandate States to put certain rights on hold if the state is confronted with a situation of emergency. IHL, on the other hand, cannot be suspended unless under critical situations as provided in Article 5 to the Fourth Geneva Convention. It must, however, be noted that certain fundamental rights like the right to life, the prohibition of torture and inhuman punishment or treatment, the right to freedom of expression, conscience and religion (ICRC, 2010) and so on have to be respected by states at all times and cannot be waived or suspended.

\subsection{The Syrian Crisis of 2011 and the UN Principle of "The Responsibility to Protect"}

The North and South divide are also evident in the application and practice of IHL and International human right law. A typical case that can be used to illustrate this situation is the Syrian civil war which started in the early parts of the year 2011 where the United States, France and the United Kingdom (global North countries) took a particular stand and supported military actions whiles China and Russia (global South countries) on the other hand also took a different point of view and vetoed out any resolution intended to use military action in Syria. Whiles, this power play between the United States, France and UK on one hand and China and Russia, on the other hand, was going on, the Syrian crisis continued to claim millions of lives and destroyed lots of properties. This phenomenon gave room and enough reasons for scholars to question the effectiveness and essence of the UN principle of "The Responsibility to Protect".

The principle of Responsibility to Protect is a political commitment that was unanimously adopted by all members of the UN at the 2005 World Summit with the aim of preventing genocide, war crimes, ethnic cleansing and crimes against humanity (Bellamy, 2011). The basis of this principle is the respect for International law, norms and practice, especially international laws that are related to human right and humanitarian laws, peace and security, armed conflict and sovereignty. The principle provides a framework that empowers the UN to use measures such as mediation, economic sanctions etc. to ensure that the human rights of civilians are protected in the event of a civil war or political conflict. The principle mandates the Security Council as the only body authorized to use force, however, the use of force should be the last resort (Allo, 2009).

The United Nations (UN) Charter of 1945 grants a permanent seat to five countries on the UN Security Council. These five countries are the United Kingdom, France, United States of America (USA), Russia and the People's Republic of China. Each of these five members possesses the power of veto which provides them with the means 
to prevent the acceptance of any substantive resolution of the UN Security Council on the use of force irrespective of the international support for that particular draft. By implication, it means that even if one permanent member of the UN Security Council vetoes a draft resolution, that resolution automatically fails.

The Syrian crisis started in March 2011 and on October 4 of that same year, the UN Security Council drafted a resolution which was tilted "Expressing grave concern at the situation in Syria". This resolution stated that the only effective solution to the current Syrian crisis was "through an inclusive and Syrian-led political process with the aim of effectively addressing the legitimate aspirations and concerns of the population." (Mckirdy, 2017). However this resolution was vetoed by China and Russia because in the view of these two countries "addressing the legitimate aspiration and concerns of the population" which was stated in the draft as the only means of resolving the conflict was a deliberate attempt by the global North countries (the USA, France, and the UK) to oust President Bashar al-Assad out of power who is an ally of Russia. This resolution stressed on the fact that the Syrian government should recognize and take into consideration the wish and aspirations of the Syrian citizens and also allows the enjoyment of the fundamental freedom and rights of the Syrian citizens. Russia and China argued that Syria is a Sovereign Country and the draft resolution infringes on the sovereignty of Syria hence the two countries vetoed this resolution.

On February 4, 2012, the Council drafted another resolution that sought to express "grave concern at the deterioration of the situation in Syria," and "profound concern at the death of thousands of people... calling for an immediate end to all violence." (Mckirdy, 2017). Again, the USA, France and the UK agreed to this resolution but Russia and China vetoed this resolution on the basis that the use of the military invention in Syria will have negative repercussions on the country and the world at large.

On May 22, 2014, China and Russian vetoed another resolution that sought to punish perpetrators of violence who in one way or the other might have violated human rights and humanitarian laws in the Syrian Crisis both from the side of the government and that of the opposition.

Two years later, thus on October 8, 2016, the forces of the Syrian president descended heavily on Aleppo which was by then captured by rebels. This resulted in the loss of millions of lives and the destruction of thousands of properties. The UN Security Council attempted to pass a resolution called the "grave distress" which sought to raise awareness about the rise of the death toll as well as the extent to which citizens in Syria are in need of humanitarian assistance. In fact as about at that time, almost 13.5 million people in Syria were in need of humanitarian assistance. The USA, France and the UK voted yes, however, Russia again vetoed this resolution but China abstained.

On December 5, 2016, another resolution drafted by the Council was again vetoed by China and Russia. This resolution sought to call on all parties involved in the crisis to cease fire and avoid any form of attack in the city of Aleppo for a period of seven days so as to allow the UN to attend to humanitarian needs of citizens in that city. The resolution also called on all parties to grant unimpeded access to humanitarian assistance to the UN and its partners (Security Council, 2016).

Furthermore, another resolution which sought to impose sanctions on parties that were guilty to have produced and use chemical weapons in the crisis was vetoed by China and Russia. Though both China and Russia supported a resolution in September 2013 to allow investigation and destruction of chemical weapons in Syria, the two countries were not in support of a resolution that sought to impose sanctions on parties that were found guilty of the use of chemical weapons in the Syrian war.

The last resolution that has been vetoed by Russia happened when a gas attack was launched on Khan Sheikhoun in Idlib province. This resolution aimed at calling for an international investigation and punishment of perpetrators of the gas attack launched on Khan Sheikhoun in Idlib province (Roth, 2017). China this time around abstained but Russia once again vetoed out this resolution. This was the eighth time that Russia has vetoed a resolution since the Syrian crisis started. In the words of the US Ambassador to the UN by name Nikki Haley, this veto by Russia implies that Russia disagrees with ensuring accountability and refuses to corporate with the UN investigation and also it meant that Russia has said no to process of peacekeeping in Syria. This event deepened the sharp difference and "antagonism" between the US and Russia.

According to Russia, the United Kingdom, France, and the US who supported the resolution were hasty and rushed into judgment without considering all the details in the resolution. Deputy Russian UN Ambassador Vladimir Safronkov defended the position of Russia and justified why Russia voted against that resolution. He argues that there was a huge problem with that draft resolution which needed to be dealt with. In his words, the draft resolution had already appointed a guilty party prior to a supposed independent and objective investigation. He added that such an act compromises the objectives of that resolution and also such an act is not compatible 
with international legal norms and standards.

According to the then UK Ambassador to the UN in the person of Matthew Rycroft "regardless of the veto today, trust these words: We will hold the regime to account. We will continue to work with our international partners to put an end to the use of chemical weapons." (Roth, 2017).

It was not until $31^{\text {st }}$ December 2016 that members of the UN Security Council unanimously adopted a resolution to help solve the Syrian crisis through negotiations between all the factions involved in the war through a peaceful means of adopting comprehensive and effective measures to end the war in Syria (UN Security Council, 2016). This resolution mandated the Council to hold a meeting between the Syrian Government and opposition representatives in Astana with the help, support, and supervision of the United Nations. Before the adoption of this unanimous decision, humanitarian and human rights laws have been seriously abused on a large scale and lots of lives have been lost as well.

\subsection{The Case of Malaysian Airline Flight MH17 in the Year 2014}

Another incident that could be used as evidence to demonstrate the existence of the North and South divide in the application of IHL and the international human right law is the case of the Malaysian Airline flight MH17 which was shot down on $17^{\text {th }}$ July 2014 in Donetsk Oblast-Ukraine. Following this incident, the UN Security Council drafted a resolution that sought to establish an international tribunal to take legal actions against all persons that were found to be guilty with regards to the downing of the Malaysian Air flight MH17 which resulted in the death of 298 people (UN News Centre, 2015). However, the UN Security Council was not able to adopt such a resolution because whiles the USA, France, and the UK voted yes, Russia vetoed it but China decided to abstain.

This draft resolution was introduced by the then Malaysian minister of Transport in the person of Liow Tiong Lai who expressed great disappointment in the behavior of Russia after the vote. The result of the voting was as follows: Angola, China, and Venezuela abstained, the remaining 11 members of the Council voted in favour of it whiles Russia vetoed it out and since Russia is a permanent member of the UN Security Council the resolution could not be adopted. In the event that this resolution was adopted, it would have helped speed up and possibly finalize the ongoing international investigation into the cause of the crash as well as prosecute perpetrators of that action in order to seek justice for the individuals who lost their lives as a result of the shooting down of the Malaysian Airline flight MH17.

The former UN Security General Ban Ki-moon issued a statement a year after the tragedy happened of which he is quoted to have said "While the pain caused by this tragedy cannot be erased, the victims must be honored by a collective effort to ascertain the truth about the incident and ensure that any persons determined responsible will be held to account." (UN Security Council, 2015).

The right to life is a basic, fundamental and inalienable internationally accepted human right and as such it is expected that both the global developed North and global developing South countries will unite and deal with any issues that lead to or has the potential of leading to individuals losing their lives. But in the case of the shooting down of the Malaysian Airline flight MH17, it is clear that the sharp divide between the North and South countries influenced the adoption of a resolution that could have probably helped to protect an important fundamental right of people as well as seek justice for victims who lost their lives in the tragedy.

\subsection{The 2007 Draft Resolution on the Peace and Security Situation in Myanmar}

Another instance that could be used to demonstrate the existence of the North and South divide in the application of IHL and the international human right law is the 2007 draft resolution of the UN Security Council with regards to how to maintain peace and security in Myanmar. This resolution was supported by USA, UK, and France (Global Developed North countries) but China and Russia (Global Developing South Countries), on the other hand, vetoed it.

On the $12^{\text {th }}$ of January 2007 , the UN Security Council failed to adopt a resolution on how to address the peace and security situations in Myanmar due to the reason that Russia and China vetoed the resolution. The draft resolution sought to call on the Government of Myanmar to bring an end to military attacks against citizens that were in ethnic minority regions. Again the resolution also intended to call on the Myanmar Government to start an important and practical political dialogue that will usher Myanmar into a genuine democratic transition (UN Security Council, 2007). Thus the resolution intended to call on the Myanmar Government to take substantive steps to allow and guarantee rights like freedom of expression, freedom of association as well as releasing Daw Aung San Suu Kyi and other political prisoners. Other provisions in the draft resolution also sought to call on the Government of Myanmar to allow the National League for Democracy (NLD) and other political parties in the 
country to freely operate without any fear or intimidation.

China's representative in the person of Wang Guangya explained his position that he strongly opposed the draft resolution mainly because the situation is an internal affair which does not pose any threat to regional or world peace and security. He added that Myanmar is a Sovereign State and that the involvement of the Security Council in the internal affairs of Myanmar implies that the Council has exceeded its mandate and also such a process will interfere and hinder effective discussions by other agencies of the UN.

The representative of Russia Vitaky Churkin also explained the reason why Russia vetoed the resolution by saying that, the issues raised in the draft resolution are been considered by other bodies of the United Nations, for instance, the General Assembly and its Third Committee, the Human Rights Council, International Organization for Migration, World Health Organization among others, thus, the involvement of the Security Council was not necessary and will be counterproductive (UN Security Council, 2007).

Alejandrod D. Wolf, the representative of the United States said that the USA is disappointed in the Council's inability to adopt this resolution (Malone, 2007). He added that the military of the Myanmar government tortured arrested, raped and waged war on its own citizens and this resolution was indeed an important step to end the violence and human rights abuse that was perpetrated by the military of the Myanmar Government. In his words, the deteriorating human right situation in Myanmar was unbearable and it posed a threat not only to the innocent citizens of Myanmar but to international peace and security.

Emyr Jones Parry, the United Kingdom representative, also expressed his great disappointment in the Council's inability to adopt the resolution and shared his deep concern over the plight of the Myanmar people. He added that the continuous abuse of IHL and international human right laws in Burma-Myanmar keeps on rising on daily basis and such activities need to be stopped. This situation threatens the peace and security of the Burma people and has a probability of posing a great threat to world peace and security as well.

Jean-Pierre Lacroix who was the France representative also explained the position of France and said he was strongly in support of the draft resolution but was sad that the Council could not adopt the resolution. In his opinion, the Myanmar situation should be given a critical consideration and the international community needs to come together and address the peace and security of Myanmar, particularly, the disagreements between the Government's military and other armed factions in the country. The only lasting solution to this problem is to create a platform that will bring all parties together and resolve all issues in an amicable manner.

\section{Conclusion}

In conclusion, one can infer from the above that evidence to support the existence of North and South Divide in the practice of international law does not only exist in areas of International environmental laws but also this divide exists in the application and practice of international Humanitarian and Human right law as well. Thus drawing evidence from the Syrian crisis and the case of the Malaysian Airline flight of MH17, as well as the 2007 draft resolution on the peace and security of Myanmar, one can confidently argue that to a large extent permanent members of the UN Security Council are divided into global North developed countries (USA, UK, and France) and the global South developing countries (Russia and China).

This division influences voting patterns in the UN Security Council which sometimes compromises the effectiveness and usefulness of the Security Council to intervene in matters of emergency in which the lives of ordinary individuals are threatened. Mostly, the global developed North countries support a particular position and votes in favour of it while the developing global South countries on the hand also support a different position and votes in that direction. In most instances before a consensus will be reached between the five permanent members of the UN Security Council, lots of lives would have been lost and international humanitarian and human rights laws will have been abused.

The purpose of this article is not to justify or disagree with either the position and voting patterns of the globally developed North countries nor that of the globally developing South countries, but this article is to draw the attention of policy makers, NGOs, International Governmental Organization like the United Nations etc. to the continuous existence of the North and South divide in the application and practice of international Humanitarian and Human rights laws and how this phenomenon threatens world peace and human dignity, and has led to the destruction of billions of properties as well as the loss of millions of lives.

As stated earlier, the North and South divide in the application and implementation of international law started with international environmental laws with the global developed North countries advocating for collective action to protect the environment whiles the global developing South countries, on the other hand, argue for social and economic justice in practice. This to a large extent has affected the adoption, implementation, and enforcement 
of effective international environmental laws and in recent times this divide between the North and South has permeated other aspects of international law such as international humanitarian and human rights laws as demonstrated with the cases above.

It is therefore suggested that world leaders, the UN and other relevant international NGOs should take a critical look at this divide between the North and South countries so as adopt effective measures to deal with this phenomenon in order to maintain world peace and put an end to the ineffectiveness of the UN Security Council to intervene and save lives on a timely manner when the need arises.

In addition, the permeant members of the UN Security Council should as much as possible bury their ideological differences which usually underpins their voting patterns and take on a more holistic approach to addressing issues of humanitarian concerns.

Finally, there is the need for an overhaul of the entire voting pattern of the UN Security Council, especially when issues of humanitarian concerns are involved. Thus, instead of the 'veto' power been vested in the hands of the five permanent members, the Council should adopt a 'reverse consensus' or a system which would imply that if any of the permanent members would like to veto a resolution, it must convince the others (at least $50 \%$ of the non-permanent members present and voting) to agree with its position in an objective manner.

\section{Acknowledgment}

A big thank you goes to Professor Han-Long of the School of Law at Zhongnan University of Economics and Law for his supervision, guidance, assistance and above all his continuous encouragement throughout this research. We are also grateful to Rita Yayra Yekple for assisting with editing and proofreading of this article.

\section{References}

Allo, A. K. (2009). Counter-intervention, Invitation, Both or Neither: An Appraisal of the 2006 Ethiopian Intervention in Somalia. Mizan Law Review, 3(2), 201-239.

Anand, R. (2017). International environmental justice: A North-South dimension. Routledge.

Bauer, S. (2002). Africa Environment Outlook. Past, Present and Future Perspectives (Vol. 1). United Nations Envir Programme.

Bellamy, A. J. (2011). Libya and the responsibility to protect: The exception and the norm. Ethics \& International Affairs, 25(3), 263-269. https://doi.org/10.1017/S0892679411000219

Beyerlin, U. (2006). Bridging the North-South Divide in International Environmental Law. Heidelberg Journal of International Law, 66, 259-296.

Birnie, P. W., \& Boyle, A. E. (1994). International Law and the Environment. New York: Oxford University Press, 2009.

Carlson, J. C. (2012). International Environmental Law and World Order: A Problem-Oriented Coursebook, with Sir Geoffrey WR Palmer and Burns H. Weston. St. Paul, MN: Thomson Reuters.

Creswell, J. W. (2009). Research Design: Qualitative, Quantitative and Mixed Methods Approaches (3rd ed.). SAGE Publications, Inc.

Ginsburg, F. (2002). Screen memories: Resignifying the Traditional in Indigenous Media. Media Worlds: Anthropology on new terrain, 39-57.

Gonzalez, C. G. (2015). Bridging the North-South Divide: International Environmental Law in the Anthropocene.

Gonzalez, C. G. (2015). Bridging the North-South Divide: International Environmental Law in the Anthropocene. Pace Environmental Law (PELR) Review, 32(407).

International Committee of The Red Cross (ICRC). (2010). Ihl and human rights law. Retrieved December 17, 2017, from https://www.icrc.org/eng/war-and-law/ihl-otherlegalregmies/ihl-human-rights/overview -ihl-and-human-rights.htm

Investopedia. (2016). Top 25 developed and developing countries. Retrieved December 16, 2016 from https://www.investopedia.com/updates/top-developing-countries/

Malone, D. M. (2007). The International Struggle over Iraq: Politics in the UN Security Council 1980-2005. Oxford University Press on Demand.

McKirdy, E. (2017). 8 Times Russia blocked a UN Security Council resolution on Syria. Retrieved December 17, 
2017 from http://edition.cnn.com/2017/04/13/middleeast/russia-unsc syria-resolutions/index.html

Natarajan, U., \& Khoday, K. (2014). Locating Nature: Making and Unmaking International Law. Leiden Journal of International Law, 27(3), 573-593. https://doi.org/10.1017/S0922156514000211

Odeh, L. E. (2010). A Comparative Analysis of Global north and Global South Economies. Journal of Sustainable Development in Africa, 12(3), 1-12.

Roth, R. (2017). Russia vetoes UN resolution on Syria. Retrieved December 17, 2017 from http://www.cnn.com/2017/04/12/politics/assad-syria-sarin-gas/

Security Council (2016). Egypt, New Zealand, and Spain: draft resolution. Retrieved December 17, 2017 from http://www.un.org/en/ga/search/view_doc.asp?symbol=S/2016/1026

Singh, G. (2014). Is it justified to include china as a part of the "Global South" in the present context? Retrieved December 15, 2017 from https://idsa.in/askanexpert/china_global_south

Stifter, D. (n.d.). Menschenrechtliche Dimensionen des globalen Klimawandels.

UN Meetings Coverage and Press Releases. (2015). On anniversary of tragic Malaysia Airlines flight MH17, Secretary-General Says Victims Must Be Honoured by Collective Effort to Ascertain Truth. Retrieved December 19, 2017 from http://www.un.org/press/en/2015/sgsm16952.doc.htm

UN News Centre. (2015). Security Council fails to adopt proposal to create tribunal on crash of Malaysian Airlines flight MH17. Retrieved December 18, 2017 from http://www.un.org/apps/news/story.asp?NewsID=51530\#.WjhPRfnyvIU

UN Security Council. (2007). Security Council fails to Adopt Draft Resolution on Myanmar, Owing to Negative Votes by China, Russian Federation. Retrieved December 24, 2017 from https://www.un.org/press/en/2007/sc8939.doc.htm

UN Security Council. (2016). Security Council supports Russian Federation-Turkey efforts to end violence in Syria, Jump-start Political Process, Adopting Resolution 2336 (2016). Retrieved December 19, 2017 from https://www.un.org/press/en/2016/sc12663.doc.htm

\section{Copyrights}

Copyright for this article is retained by the author(s), with first publication rights granted to the journal.

This is an open-access article distributed under the terms and conditions of the Creative Commons Attribution license (http://creativecommons.org/licenses/by/4.0/). 